April 2019 Volume 2 No 2

\title{
REVENUES ANALYSIS OF TEXTILE FABRIC ARANEAE AS INNOVATION HIGH QUALITY
}

\section{ANALISIS PENDAPATAN USAHA TEKSTIL KAIN ARANEAE INOVASI BARU BERKUALITAS TINGGI}

\author{
Rizky Ramadhan ${ }^{1}$, Aanja Rahyuni Silalahi ${ }^{1}$, Zakaria Ecep $^{1}$, Adinda Nursabilla Purba ${ }^{1}$, \\ 1) Jurusan Agribisnis Fakultas Pertanian, Universitas Muhammadiyah Sumatera Utara \\ Email : yudhaandriansyah@umsu.ac.id, risky7tujuh@gmail.com
}

\begin{abstract}
Spiders (Araneae) are predatory animals that are sometimes cannibal, they eat their own species even though the main prey is insects. Almost all types of spiders can inject poison through a pair of fangs. Even so, of the tens of thousands of species of spiders that exist, only about 200 species are equipped with poisons that are harmful to humans': Araneae fabrics are the latest innovations made from unique materials. We are interested in conducting this study, citing a study by someone who said "The team of chemists from ASU learned that the molecular structure of the fiber could produce the latest technology in making materials such as vests, bulletproof to artificial tendons. The purpose of this research is to make spiders as a work of new innovations of high-quality fabrics, opening new jobs for the community, able to meet market needs, affordable prices can be felt by fabric lovers. This research is used as a momentum to attract unique and interesting spider fiber communities.The methods used in making this cloth are as follows; The initial steps that must be done are to collect the main raw materials and KANARA supporting materials, then after the tools and materials have been fulfilled, they can immediately carry out the production process beginning with the spider taken from the silk fiber, dyed with dye and chemical liquid after that spinning Using a spinning tool that will produce yarn and then the thread is sewn and formed of cloth until it is produced a fabric product made of spider webs. Fabric Operating Revenues, namely Revenue of Rp. 20,580,000 reduced by a total cost of Rp. 12,500,000 per 70 meters so as to obtain revenues of $R p .18,280,000$.
\end{abstract}

Keywords : Araneae fabrics, unique and interesting

Abstrak
Laba-laba (Araneae) adalah hewan predator yang kadang-kadang kanibal, mereka memakan spesies mereka sendiri meskipun mangsa utamanya adalah serangga. Hampir semua jenis laba-laba dapat menyuntikkan racun melalui sepasang taring. Meski begitu, dari puluhan ribu spesies laba-laba yang ada, hanya sekitar 200 spesies yang dilengkapi dengan racun yang berbahaya bagi manusia '. Kain Araneae adalah inovasi terbaru yang terbuat dari bahan unik. Kami tertarik untuk melakukan penelitian ini, mengutip sebuah penelitian oleh seseorang yang mengatakan "Tim ahli kimia dari ASU mengetahui bahwa struktur molekul serat dapat menghasilkan teknologi terbaru dalam membuat bahan seperti rompi, antipeluru hingga tendon buatan. Tujuan dari penelitian ini menjadikan laba-laba sebagai karya inovasi baru kain berkualitas tinggi, membuka lapangan kerja baru bagi masyarakat, mampu memenuhi kebutuhan pasar, harga terjangkau dapat dirasakan oleh para pecinta kain.Penelitian ini digunakan sebagai momentum untuk menarik unik dan komunitas serat laba-laba yang menarik.

Metode yang digunakan dalam pembuatan kain ini adalah sebagai berikut; Langkah awal yang harus dilakukan adalah mengumpulkan bahan baku utama dan bahan pendukung KANARA, kemudian setelah alat dan bahan tersebut terpenuhi, mereka dapat segera melakukan proses produksi dimulai dengan laba-laba diambil dari serat sutra, dicelup dengan pewarna dan cairan kimia setelah pemintalan itu Menggunakan alat pemintalan yang akan menghasilkan benang dan kemudian benang dijahit dan dibentuk dari kain sampai dihasilkan produk kain yang terbuat dari jaring laba-laba. Pendapatan Pengoperasian Kain, yaitu Pendapatan sebesar Rp. 20.580.000 dikurangi dengan total biaya Rp. 12.500 .000 per 70 meter sehingga memperoleh pendapatan sebesar Rp. 18.280.000.

Kata kunci: Kain Araneae, unik dan menarik

\section{A. PENDAHULUAN}

Laba-laba (Araneae) adalah hewan pemangsa yang terkadang kanibal, mereka memakan jenisnya sendiri meskipun mangsa utamanya adalah serangga. Hampir semua jenis laba-laba mampu menyuntikkan racun melalui sepasang taringnya. Meski begitu, dari puluhan ribu spesies laba-laba yang ada, hanya sekitar 200 
spesies yang dilengkapi racun yang berbahaya bagi manusia ‘.

Di sisi lain, laba-laba memiliki manfaat yang luar biasa yang ada pada jaringnya, karena menghasilkan tujuh jenis sutra (tipis, kuat untai protein), mulai dari lengket untuk menjebak dan membungkus mangsanya untuk benang super kuat untuk dukungan. Para tim ahli kimia dari ASU mempelajari bahwa struktur molekuler serat itu bisa menghasilkan teknologi terbaru dalam pembuatan material seperti rompi, anti peluru hingga tendon artifisial'.

Kain merupakan bahan baku utama untuk membuat pakaian sebagai kebutuhan sandang atau primer bagi masyarakat umum. Namun, seringkali terjadi kasus dimana kain yang memiliki kualitas unggul memiliki harga yang tidak terjangkau oleh masyarakat menengah kebawah, contohnya kain sutera. Maka dari itu harus ada inovasi baru kain berkualitas tinggi dengan harga yang terjangkau. Sehingga dapat dinikmati oleh masyarakat luas.

Tetragnathidae merupakan famili yang memiliki kelimpahan tertinggi, dan dominan ditemukan pada lahan perkebunan. Famili ini umumnya melimpah pada rerumputan atau vegetasi rendah, dan sangat jarang ditemukan pada pohon yang tinggi. Tetragnathidae merupakan laba-laba pembuat jaring. Hasil penelitian (Herlinda et al 2014) melaporkan bahwa Tetragnathidae merupakan laba-laba pembuat jaring. Sebaliknya, Tetragnathidae, seperti Tetragnatha vermiformis Emerton ditemukan pada permukaan tanah. Hal ini dapat disebabkan oleh perilaku spesies tersebut walaupun pembuat jaring, tetapi mampu bergerak dan berjalan di permukaan tanah dan air. Beberapa peneliti melaporkan bahwa Tetragnathidae merupakan famili yang dominan ditemukan selama penelitian'

Laba-laba adalah agen pengendalian hayati yang potensial terhadap hama tanaman. Banyak jenis laba-laba yang telah dilaporkan memangsa beragam jenis hama pada tanaman pertanian. Pada tanaman kacang-kacangan ditemukan beragam jenis laba-laba yang potensial untuk dimanfaatkan secara optimalb untuk menekan perkembangan populasi hama'

Dari hasil Wawancara kami kebeberapa ibu-ibu dan juga pemilik usaha penjualan kain kami dapat menarik kesimpulan bahwa mereka masih sulit untuk mencari kain yang berkualitas dan memiliki harga yang terjangkau. Jika ada itupun pasti akan dibandrol dengan harga yang mahal.
Sehingga kain-kain yang berkualitas hanya bisa dinikmati oleh kalangan tertentu.

Dari hasil observasi kami dilapangan kami juga menemukan bahwa kain-kain yang berkualitas ini jarang sekali diproduksi secara masal dalam bentuk jadi (pakaian). Karena peminatnya tidak terlalu banyak yang disebabkan harga yang mahal, Tidak jarang orang-orang yang ingin mempunyai pakaian yang baik kualitasnya mereka memesan dan menjahitkan di tukang jahit atau perancang busana. Oleh sebab itu kami disini ingin membuat inovasi baru dimana kain yang bagus bisa diproduksi masal dalam bentuk jadi dan dapat dinikmati hampir disemua kalangan.

\section{B. METODE PENELITIAN}

Metode yang digunakan dalam peneletian ini adalalah metode deskripsi analisis. Wawancara serta hasil observasi dilapangan yang dilakukan mendapatkan informasi kain yang dijual dipasaran memiliki kualitas yang rendah, jika kualitas kain bagus maka harga begitu mahal. Dengan demikian penelitian ini bertujuan untuk mempermudah kalangan menengah kebawah yang ingin merasakan kualitas kain terbaik dengan harga yang dapat dijangkau. Analisis data Bertujuan Untuk Mengetahui :

\section{HASIL DAN PEMBAHASAN}

Untuk mengetahui bagaimana usaha tekstil, maka analisis data di lakukan dengan menggunakan metode deskriptif dan hasil penelitian akan di sajikan dalam bentuk tabel. Untuk mengetahui total penerimaan per 70 meter dapat di tentukan dengan menggunakan rumus berikut: $\mathrm{TR}=\mathrm{Q}$ x $\mathrm{P}$ Dimana : $\mathrm{TR}=$ Total Revenue $/$ Total penerimaan $(\mathrm{Rp}) \mathrm{Q}=$ Quantity/ Jumlah produksi $(\mathrm{Kg}) \mathrm{P}=$ Price / Harga (Rp) Sedangkan untuk mengetahui tingkat pendapatan petani, maka analisis data menggunakan analisis pendapatan usahatani yang di hitung menggunakan formulasi : $\mathrm{I}=\mathrm{TR}-\mathrm{TC}$ Dimana : $\mathrm{I}$ = Pendapatan usahatani (income) $\mathrm{TR}=$ Total penerimaan (Total Revenue) $\mathrm{TC}=$ Total biaya (Total Cost) Analisis pendapatan kemudian di lanjutkan dengan analisis Cost of Ratio (R/C), yang merpakan analisis perbandingan antara peneriamaan usaha dengan total biaya produksi. Analisis ini menggunakan model persamaan sebagai berikut: $\mathrm{A}=\mathrm{TR} / \mathrm{TC} \mathrm{TR}=$ $\mathrm{P} \cdot \mathrm{Q} \mathrm{TC}=\mathrm{FC}+\mathrm{VC} \mathrm{R} / \mathrm{C}=((\mathrm{P} . \mathrm{Q}) /(\mathrm{FC}+$ VC) ) Dimana : $\mathrm{A}=$ Indeks Kelayakan Usahatani $\mathrm{R} / \mathrm{C}=$ Rasio perbandingan antara total penerimaan dan total biaya produksi $\mathrm{TR}=$ Total Penerimaan TC = Total Biaya $\mathrm{P}=$ Price $($ Harga) $\mathrm{Q}=$ Quantity (Total Produksi) FC = Fixed Cost (Biaya Tetap) $\mathrm{VC}=$ Variable Cost (Biaya Variabel) Dengan kriteria, apabila : Bila $\mathrm{R} / \mathrm{C}=1$, usahatani tersebut tidak untung dan tidak rugi Bila $\mathrm{R} / \mathrm{C}<1$, 
usahatani tersebut rugi Bila $\mathrm{R} / \mathrm{C}>1$, usahatani tersebut untung.

1.Hipotesis Pertama

Pengujian Hipotesis Pertama yaitu diduga tingkat Pendapatan dari usaha kain lebih besar dari biaya yang dikeluarkan per meter, dilakukan dengan cara tabulasi deskriptif analisis terhadap data yang diperoleh dari kuisoner. Tingkat Pendapatan pengusaha Kain dan variable-variable yang berpengaruh terhadap pendapatan pengusaha kain pertahun dilakukukan analisis pendapatan usahakain araneaae dapat dihitung dengan mengurangkan pendapatan dengan seluruh biaya yang benar-benar dikeluarkan. Secra matematis sebagai berikut:

$\mathrm{TC}=\mathrm{TFC}+\mathrm{TVC}$ (soekartawi, 2005)

Keterangan :

$\mathrm{TC}=$ Total Biaya

TFC = Total Biaya Tetap

TVC = Total Biaya Variabel

Penerimaan Menurut (soekartawi, 2005)

$$
\mathbf{T R}=\mathbf{Q} * \mathbf{P}
$$

Keterangan :

$$
\begin{array}{ll}
\text { TR } & =\text { Penerimaan Total }(\mathrm{Rp}) \\
\mathrm{Q} & =\text { Jumlah Produksi } \\
\mathrm{P} & =\text { Harga }(\mathrm{Rp})
\end{array}
$$

Pendapatan menurut (soekartawi, 2005)

$$
\begin{array}{ll} 
& \text { NR }=\text { TR-TC ekspilit } \\
\text { TR } & =\mathbf{Q} * \mathbf{P} \\
\text { TC } & =\text { TFC }+ \text { YVC }
\end{array}
$$

Keterangan :

$$
\begin{array}{ll}
\mathrm{TR} & =\text { Penerimaan Total }(\mathrm{Rp}) \\
\mathrm{TC} & =\text { Total Biaya }(\mathrm{Rp}) \\
\mathrm{Q} & =\text { Jumlah Produksi } \\
\mathrm{P} & =\text { Harga }(\mathrm{Rp}) \\
\mathrm{TVC} & =\text { Total Biaya variabel }(\mathrm{Rp}) \\
\mathrm{TFC} & =\text { Total Biaya Tetap }(\mathrm{Rp})
\end{array}
$$

\section{Biaya Tetap (Fixed Cost )}

Biaya tetap (fixed cost ) adalah biaya yang tidak berpengaruh oleh besar kecilnya biaya produksi yang dihasilkan. Biaya tetap pada analisi pendapatan pengusaha kain ini meliputi biaya penunjang untuk usaha kain. Seperti yang ditunjukan dalam Tabel 1.

Tabel 1. Rata-rata biaya Tetap ( Fixed cost ) usaha

\begin{tabular}{ll}
\hline \multicolumn{1}{c}{ Keterangan } & \multicolumn{1}{c}{ Jumlah } \\
\hline Sewa alat pintal & Rp. 1.700 .000 \\
\hline Sewa mesin jahit & Rp. 500.000 \\
\hline SewaTempat Produksi & Rp 2.400.000 \\
\hline Kompor gas & Rp. 350.000 \\
\hline Panci & Rp. 250.000 \\
\hline $\begin{array}{l}\text { Masker } \\
\text { Biaya Tetap/ Fixed } \\
\text { cost }\end{array}$ & Rp.5.480.000 \\
\hline \begin{tabular}{l} 
berkualitas tinggi. \\
\hline
\end{tabular}
\end{tabular}
kain berkualitas tinggi.

Berdasarkan tabel 1. Biaya tetap papda usaha kain araneae adalah sebesar Rp5.480.000.

\section{Biaya Variabel ( Variable Cost)}

Biaya variable ( Variable Cost) adalah biaya yang dikeluarkan dalam proses produksi yang besarnya berubah-ubah tergantung dari besar kecilnya produksi. Biaya variabel pada analisi pendapatan pengusaha kain ini meliputi biaya bahan habis pakai, perjalanan serta biaya lain-lain. Seperti yang tertera pada tabel 2 .

\begin{tabular}{ll}
\hline $\begin{array}{l}\text { peralatan merangkai } \\
\text { lainnya }\end{array}$ & Rp.300.000 \\
\hline Biaya budidaya & Rp. 1000.000 \\
\hline Sewa lahan budidaya & Rp. 450.000 \\
\hline $\begin{array}{l}\text { Pembuatan rumah } \\
\text { kaca mini }\end{array}$ & Rp. 2.720 .000 \\
\hline Transportasi & Rp. 100.000 \\
\hline $\begin{array}{l}\text { Pembuatan logo dan } \\
\text { Desain }\end{array}$ & Rp Rp.700.000 \\
\hline Brosur iklan & $R p .300 .000$ \\
\hline Variabel Cost & Rp 6.470 .000 \\
\hline
\end{tabular}


Dari tabel 2. Rata-rata Biaya materil habis pakai Rp. 6.470.000, biaya taransportasi Rp 1.000.000 dan biaya lain-lain sebesar Rp 1.000.000untuk biaya pembuatan kain araneae.

\section{Biaya Total ( Total Cost )}

Biaya total merupakam biaya dari penjumlahan Fixed cost (FC) dengan Variable Cost (VC) yang digunakan dalam proses produksi. Dari hasil penelitian maka didapat hasil seperti pada tabel 3 .

\section{Keterangan}

Jumlah

Biaya Tetap/ Fixed Cost $\quad$ Rp 5.480.000 (FC)

$\begin{array}{cc}\text { Biaya Varabel / } & \text { Rp } 6.470 .000 \\ \text { Variable Cost (VC) }\end{array}$

Biaya Total / Total Cost Rp.12.500.000 (TC)

\section{Penerimaan}

Penerimaaan Usaha Kanara merupakan hasil kali antara kuantitas kain yang dihasilkan dalam satuan meter dan harga jual kain dalam satuan rupiah (Rp). Tabel 4 merupakan hasil penerimaan penelitian. Dalam penelitian ini, total penerimaan didapatkan dari mengalikan jumlah produksi kain yang didapat dikalikan dengan harga kain yang berlaku pada saat penelitian, yaitu harga per meter sebesar Rp. 294.000. pada tabel 5 menu jukkan penerimaan dari usaha kain per meter yaitu sebesar Rp.20.580.000.

Tabel 5. Rata-rata Produksi dan Penerimaan total usaha kain araneae

\begin{tabular}{ll}
\hline Keterangan & Jumlah \\
\hline Produksi $\left(\mathrm{m}^{2}\right)$ & $70 \mathrm{M}$ \\
\hline Harga permeter & 294.000 \\
\hline Penerimaan & 20.580 .000 \\
\hline
\end{tabular}

\section{Pendapatan}

Pendapatan Pada usaha kain diartikan sebagai selisih antara besarnya penerimaan dan biaya yang dikeluatkan (total biaya). Tabel 6 . Merupakan daftar pendapatan hasil usaha kain berkualitas tinggi.

Tabel 6. Rata-rata Pendapatan Usaha kain

\begin{tabular}{lc}
\hline Keterangan & Jumlah \\
\hline Total Penerimaan & 20.508 .000 \\
\hline Total Biaya & 12.5000 .000 \\
\hline Pendapatan & Rp 18.280.000 \\
\hline $\begin{array}{c}\text { Berdasarkan } \\
\text { baha }\end{array}$ & $\begin{array}{c}\text { Tabel } \\
\text { usaha } 6, \text { dapat ditarik } \\
\text { kesimpulan memperoleh } \\
\text { pendapatan per 70 meter sebesar Rp 18.280.000. }\end{array}$
\end{tabular}

D. KESIMPULAN

1. Biaya dari usaha kain araneae yaitu biaya Tetap Rp5.480.000 dan biaya variabel $\mathrm{Rp}$ 6.470 .000 sehingga diperoleh biaya total sebesar Rp 12.500.000.

2. Hasil Produksi Rata-rata sebesar 70 meter dengan harga jual Rp. 290.000 maka total penerimaan dari usaha kain adalah $\mathrm{Rp}$ 20.580.000.

3. Pendapatan Usaha kain yaitu Penerimaan Rp 20.580.000 dikurangi dengan total biaya $\mathrm{Rp}$ 12.500.000 per 70meter sehingga diperoleh pendapatan sebesar Rp 18.280.000..

\section{SARAN}

Pengusaha kain menambah produktivitas agar keuntungan yang diperoleh lebih besar. Pengusaha kain juga harus memperhatikan strategi pemasaran serta selera kain dipasar, serta memperbaiki kualitas kain sehingga target pasar tinggi.

\section{DAFTAR PUSTAKA}

Barrion AT, V. S. (2012). the spider fauna in the rice agricultural landscape of hainan island,china:composition, abundance and feeding structure. the asian international journal of life sciences 21, 625-651.

Barrion AT, V. S. (n.d.). the spider fauna in the rice agricultural landscapeof hainan island.

bern. (2015, november 27). natural histrory тиеит. Dipetik november 27, 2015, dari currently valid spider general and spesies: currently valid spider general and spesies

DJ, h. (1998). ecogical approach to pest managemen. new york: the fullford press.

foelix, r. F. (1996). A.S:oxford university. new york: perss.hlm 3.ISBN 0-19-509593-6. soekartawi. (2005). matematic, 18-21. 